\title{
AN EFFICIENT APPROACH TO MANAGE DOMESTIC WASTEWATER IN SMART CITY
}

\author{
A.Taouraout ${ }^{1,2, *}$, A. Chahlaoui ${ }^{2}$, D. Belghyti ${ }^{1}$, I. Taha $^{2}$, M. Lachhab ${ }^{1}$ \\ ${ }^{1}$ Laboratory of Agrophysiology, Biotechnology, Environment and Qualities, Faculty of Sciences, University IbnTofail of \\ Kenitra, BP: 133, 14000 Kenitra Morocco. \\ ${ }^{2}$ Laboratory of Natural Resources Management and Development Team, Health and Environment, Faculty of Science, \\ Moulay Ismail University Meknes, Morocco.
}

Commission VI, WG VI/4

KEY WORDS: Vertical Multi-soil-layering, performance, Hydraulic loading rate, Management, Wastewater, Smart city, Morocco.

\begin{abstract}
:
The adoption of an ecological sanitation system, meeting the requirements hygienic and sanitary, constitutes a feasible and technically and economically acceptable solution in the future smart city. This new sanitation concept has the advantage of solving the problems of pathogens of human waste at source, thus offering the possibility of reusing them after treatment (recycling) in order to improve the standard of living of the population and protect the environment. The aim of this study is to evaluate the efficiency of a vertical Multi-Soil-Layering system (MSL) system to treat domestic wastewater under three hydraulic loading rates: $250 \mathrm{~L} / \mathrm{m}^{2} / \mathrm{day}$, $350 \mathrm{~L} / \mathrm{m}^{2} /$ day and $500 \mathrm{~L} / \mathrm{m}^{2} /$ day, in Moroccan conditions. To do this, a vertical MSL system measuring $20 \mathrm{~cm} \times 60 \mathrm{~cm} \times 78 \mathrm{~cm}(\mathrm{~L}$ $\times \mathrm{W} \times \mathrm{H}$ ) was designed to treat domestic wastewater and his performance was investigated. The results showed high removal of organic matters and nutrients under the three hydraulic loads tested; the performance averages recorded are upper than $84 \%$ for organic matters, $83.1 \pm 7.2 \%$ for ammonium and $72.4 \pm 14.1 \%$ for orthophosphate. The quality of the treated wastewater was evaluated according to Moroccan reject limit value. Consequently, this system could be considered an effective solution to be adopted for decentralized domestic wastewater treatment in Moroccan conditions.
\end{abstract}

\section{INTRODUCTION}

Currently, there is a risk that several cities will face water shortage, lack of water quality, lack of sanitation and environmental pollution in general. The situation is further exacerbated especially in developing countries due to the combined effects of population growth and low socio-economic status (Vymazal, 2011; Wu et al., 2014); this is one of the factors behind population expansion is rural migration. People come to cities looking for employment opportunities. Unfortunately, in many cities of developing countries, people live and raise their children in a highly polluted environment. Moreover, there is the issue of weak or almost non-existent policies on more efficient water usage. Also, water management plans are not based on demand, reuse and recycling. Wastewater is often not given much importance. Consequently, in 2015, 2.4 billion people worldwide lacked improved sanitation (United Nations, 2016); and more than 2,000 million tons of human waste are discharged directly into the wild every year, without any treatment (UN-HABITAT, 2009). These practices still pose a major risk to public health and the environment; exposing many people to infection and dangerous diseases (Galloway et al., 2004; WHO, 2005; Sutton et al., 2011). In fact, human excrement can contain pathogenic agents such as bacteria and parasites capable of causing diarrheal diseases (cholera, typhoid, etc.) (Berrada, 2007). According to Jewitt (2011), food and drinking water can be contaminated with these pathogens through insects and human contact. This is why, in these countries, there is a high percentage of the population that is already attacked by waterborne diseases; this population becomes vulnerable to potential infections and malnutrition sulfur (Heinonen-Tanski, van Wijk-Sijbesma, 2005). As a

*Corresponding author result, an estimated 1.5 million people die each year from lack of access to clean water and the presence of pathogens associated with human excrement (Farmer, 2001; UNICEF/WHO, 2008).

Rather than linear thinking about systems and technical solutions, smart city will need to think more about ecosystems and the 'water web'. This new approach integrates the social, cultural, economic and ecological aspects. Indeed, the ecosystem, social and resource problems in urban settings are all interrelated. In particular, better management of the water resource, storm water and wastewater can often be achieved by addressing the total urban water system. In addition, wastewater management is also about the wise use of our natural resources such as water, nutrients and even energy (Ferguson et al., 2003; Taouraout et al., 2020a; Taouraout et al., 2020b).

To compete effectively at an international level, cities will need to become more intelligent, innovative, and integrated. A Smart City will increase efficiency, productivity, ecological awareness; it will reduce pollution and improve quality of life in a world of increasing urban complexity. Smart cities concept is pragmatic and balanced combination of ecological, economical and other effective field for perfect sustainable development. Ecological cities enhance the well-being of citizens and society through integrated urban planning and management that fully harnesses the benefits of ecological systems, and protects and nurtures these assets for future generations (Taouraout et al., 2020a; Taouraout et al., 2020b).

In general, the sanitation concept to be adopted in smart cities must integrate not only the water aspect (transport, flow) but also the treatment in order to protect the receiving environment from the risks of contamination (Taouraout et al., 2020a; 
Taouraout et al., 2020b). Indeed, the concept of the linear approach sanitation "end of pipe" (Figure 1), in which resources are used and converted into wastes, only to be disposed of, represents a failure in human ingenuity and a flaw in technology design.

The adoption of an ecological sanitation system (Figure 2), meeting the requirements hygienic and sanitary, constitutes a feasible and technically and economically acceptable solution in the future smart city (Taouraout et al., 2020a; Taouraout et al., 2020b). This new sanitation concept (ecological sanitation) has the advantage of solving the problems of pathogens of human waste at source, thus offering the possibility of reusing them after treatment (recycling) in order to improve the standard of living of the population and protect the environment (Ferguson et al., 2003; Taouraout et al., 2020a; Taouraout et al., 2020b).

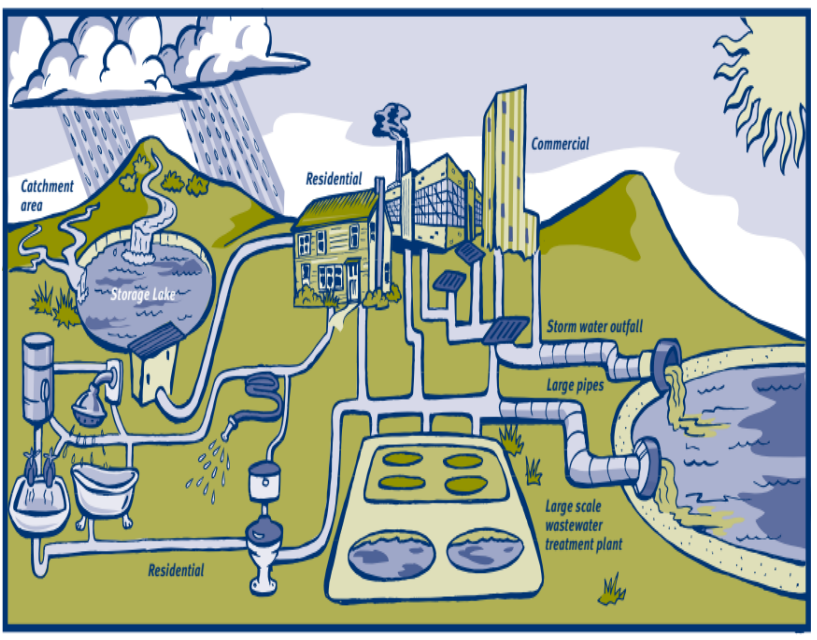

Figure 1. Leaner sanitation "end of pipe" (Ferguson et al., 2003).

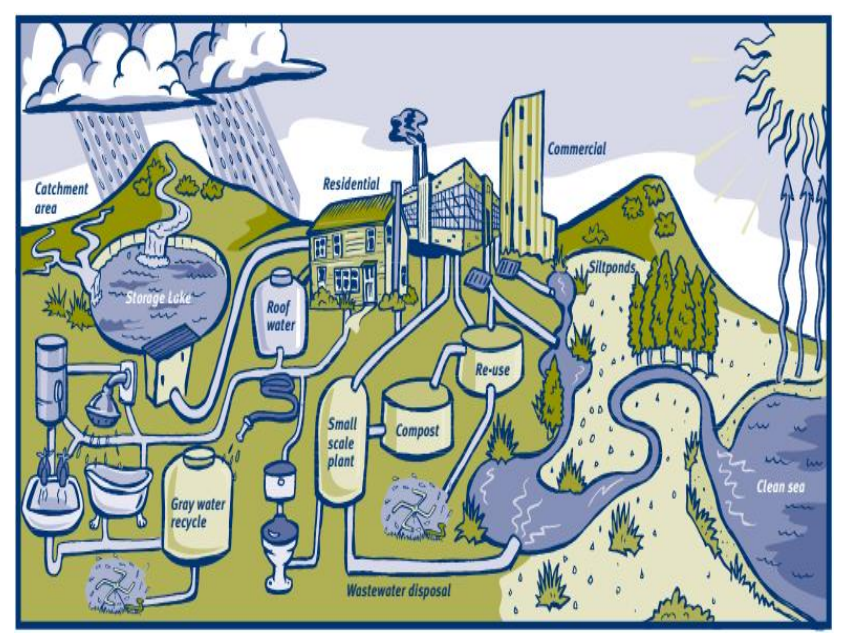

Figure 2. Ecological sanitation "treatment and recycling"

(Ferguson et al., 2003)

One efficient approach to treat domestic wastewater is through an economic, ecological and sustainable technic called MultiSoil-Layering system (MSL). The first MSL system was developed in Japan (1990), to treat wastewater. Compared with conventional soil treatment systems, this system could withstand a higher hydraulic loading rate (HLR) and was less prone to clogging (Masunaga et al., 2007; Ho, Wang, 2015). The MSL system uses high quantities of natural, unpolluted materials to produce reusable water for eco-environment or agriculture, washing cars and toilet flushing (Chen et al., 2009). Contrary to the traditional system (e.g. lagooning), this system can be maintained and operated at a low cost, requires only a small land area, and is ideal for urban areas in developing countries (Luanmanee, et al., 2002). The MSL system primarily comprises soil mixture blocs (SMBs) and permeable layers (PLs). The aim of this study is to evaluate the efficiency of a vertical Multi-Soil-Layering system (MSL) system to treat domestic wastewater under three hydraulic loading rates: 250 $\mathrm{L} / \mathrm{m}^{2} /$ day, $350 \mathrm{~L} / \mathrm{m}^{2} /$ day and $500 \mathrm{~L} / \mathrm{m}^{2} /$ day, in Moroccan conditions.

\section{MATERIEL AND METHODS}

\subsection{Description of the treatment unit}

The pilot-scale treatment system used in this study is a Vertical Multi-Soil-Layering (V-MSL) measuring $20 \mathrm{~cm}$ x $60 \mathrm{~cm}$ x $78 \mathrm{~cm}$ $(\mathrm{L} \times \mathrm{W} \times \mathrm{H})$ with a feeding tank (100L) used to store pre-screened wastewater from the inlet of the household wastewater using submersible pump. Figure 3 shows a detailed description of this MSL structure. This pilot-scale was carried out in a single household (Meknes, Morocco); where the climate is classified as warm temperate. It was designed, built and began to operate at the beginning of March 2017 and, this system was allowed to stabilize for three months. This MSL system was composed of soil mixture blocks (SMBs) arranged in a brick-like pattern and surrounded by permeable layers (PL) composed by gravel $(\emptyset=3-5 \mathrm{~mm})$. The SMB comprised by sandy soil $(60 \%)$, wood sawdust (20\%), charcoal (10\%), and iron sawdust (10\%) at a dry weight. The mixture was packed into square Hemp bag (Block) measuring $20 \mathrm{~cm}$ in width and $4 \mathrm{~cm}$ in height. In this filter, we used two types of block which differed mainly in the width: $16 \mathrm{~cm}$ for block A and $8 \mathrm{~cm}$ width for block B (Figure 3).

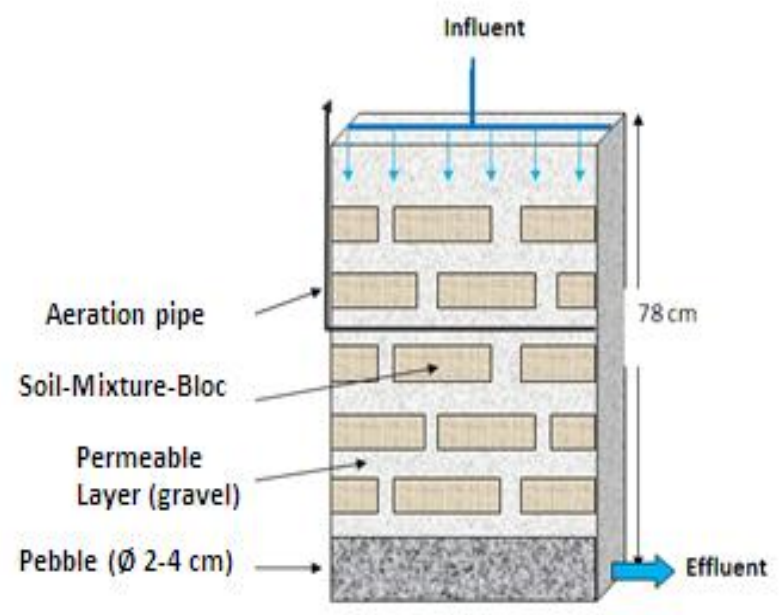

Figure 3. Schematic representation of Vertical Multi-SoilLayering

The filling of the filter is done in the following order: the first layer $(20 \mathrm{~cm}$ thick) is composed by the pebbles followed by the first permeable layer $(5 \mathrm{~cm}$ thick of gravel) followed by the first layer of bricks (SMBs); the alternation of the permeable layers and the brick layers succeed one another until the sixth permeable layer. The bricks are arranged horizontally with a space of $5 \mathrm{~cm}$ between them. 


\subsection{Measurement of water quality parameters}

After the stabilization period (three months), samples of raw and treated water were collected at the same time each month (from June 2017 until April 2018). Samples were analyzed for different water quality parameters using the French standard methods (Rodier et al., 2009). Temperature (T), pH, and Dissolved Oxygen (DO) were measured in situ using a multiparameter probe type PCE-PHD1 and turbidity by Turbidity meter (HI 93703 HANNA instruments). The other parameters were measured into Laboratory of Natural Resources Management and Development Team, Health and Environment (Faculty of Science Meknes). Biochemical oxygen demand measured in a 5 day test (BOD) ${ }_{5}$ ) was determined by the BOD Sensor (VELP SCIENTIFICA), and chemical oxygen demand (COD) was analyzed according to the dichromate open reflux method. Total suspended solids (TSS) concentration was determined by the filtration method, ammonium $\left(\mathrm{NH}_{4}{ }^{+}\right)$ concentration by the indophenol method, and orthophosphate $\left(\mathrm{PO}_{4}{ }^{3-}\right)$ concentration by the molybdate and ascorbic acid method.

\subsection{Data analysis}

Statistical analyses of the collected data were carried out using software: Microsoft Excel 2010, SPSS 20 (Analysis of variance test (ANOVA)). In this study, the objective of the ANOVA test is to investigate whether there is a significant difference between the characteristics of the sample before and after treatment with a significance level (p) and the effect of hydraulic load rates on the performance of V-MSL.

\section{RESULTS}

\subsection{General parameters}

The results in Table 1 showed an increase of turbidity values when HLR increased; in the contrary, dissolved oxygen decreased when HLR increased. The average values of DO for $250 \mathrm{~L} / \mathrm{m}^{2} /$ day, $350 \mathrm{~L} / \mathrm{m}^{2} /$ day and $500 \mathrm{~L} / \mathrm{m}^{2} /$ day were $(4.5 \pm 0.5)$ $\mathrm{mg} / \mathrm{L},(4.4 \pm 0.6) \mathrm{mg} / \mathrm{L}$ and $(3.5 \pm 1.5) \mathrm{mg} / \mathrm{L}$, respectively. On the other hand, $\mathrm{pH}$ values are almost similar for all HLRs tested; however, the different values of temperature recorded for the HLRs are related to the month of the year. ANOVA test did not show any significant difference between the averages of these parameters for all HLRs tested.

\begin{tabular}{|l|c|c|c|c|c|}
\hline $\begin{array}{l}\text { HLR } \\
\left(\mathrm{L} / \mathrm{m}^{2} / \text { day }\right)\end{array}$ & $\begin{array}{c}\mathrm{T} \\
\left({ }^{\circ} \mathrm{C}\right)\end{array}$ & $\mathrm{pH}$ & $\begin{array}{c}\mathrm{EC} \\
(\mathrm{mS} / \mathrm{cm})\end{array}$ & Turbidity & $\begin{array}{c}\mathrm{DO} \\
(\mathrm{mg} / \mathrm{L})\end{array}$ \\
\hline 250 & 20.9 & 7.4 & $0.87 \pm 0.2$ & $17.9 \pm 9.6$ & $4.5 \pm 0.5$ \\
350 & 17.6 & 7.3 & $1.03 \pm 0.1$ & $19.8 \pm 6.5$ & $4.4 \pm 0.6$ \\
500 & 22.0 & 7.5 & $0.97 \pm 0.4$ & $25.6 \pm 6.5$ & $3.5 \pm 1.5$ \\
\hline
\end{tabular}

Table 1. Temperatures, $\mathrm{pH}, \mathrm{EC}$, turbidity and $\mathrm{DO}$ values into the filter according to the HLR

\subsection{Reduction of $\mathrm{BOD}_{5}$, COD and TSS}

The concentration of $\mathrm{BOD}_{5}, \mathrm{COD}$ and TSS in the inlet and outlet and their removal efficiency, during the study period under various HLRs, are shown in Table 2 and Figures 4 to 6 . The results indicated these parameters achieved $(85.2 \pm 6.0) \%$, $(83.8 \pm 7.5) \%,(88.3 \pm 7.2) \%$ removal, respectively, when the HLR1 = $250 \mathrm{~L} / \mathrm{m} 2 /$ day; with HLR2 $=350 \mathrm{~L} / \mathrm{m} 2 /$ day, they achieved $(85.9 \pm 5.5) \%, \quad(87.1 \pm 4.7) \%$ and $(87.9 \pm 4.4) \%$, respectively, and with $\mathrm{HLR} 3=500 \mathrm{~L} / \mathrm{m} 2 /$ day, they achieved $(83.0 \pm 7.3) \%,(82.1 \pm 8.3) \%$ and $(84.6 \pm 10.5) \%$, respectively.

\begin{tabular}{|l|c|c|c|c|}
\hline $\begin{array}{l}\text { HLR } \\
\left(\mathrm{L} / \mathrm{m}^{2} / \text { day }\right)\end{array}$ & & BOD $_{5}$ & COD & TSS \\
\hline \multirow{3}{*}{250} & Influent (mg/L) & 156 & 326.5 & 339.1 \\
& V-MSL (mg/L) & 21.5 & 49.9 & 36.5 \\
& $\%$ removal & 85.2 & 83.8 & 88.3 \\
350 & Influent (mg/L) & 171.8 & 383.8 & 297.3 \\
& V-MSL (mg/L) & 23.5 & 48.5 & 36 \\
& $\%$ removal & 85.9 & 87.1 & 87.9 \\
\multirow{3}{*}{500} & Influent (mg/L) & 232.1 & 450 & 477.6 \\
& V-MSL (mg/L) & 39.07 & 79.2 & 71.76 \\
& \% removal & 83.3 & 82.1 & 84.6 \\
\hline
\end{tabular}

Table 2. Removal performance of organic matters under different HLRs

These results suggested that the removal rate of these parameters decreased as the HLR increased. This is because the retention time of the wastewater within the system increased as the HLR decreased, thus providing the system with sufficient time to adsorb, react, and remove the organic pollutants from the wastewater and consequently enhancing the removal efficiency (Masunaga et al., 2007; Taouraout, et al., 2019).

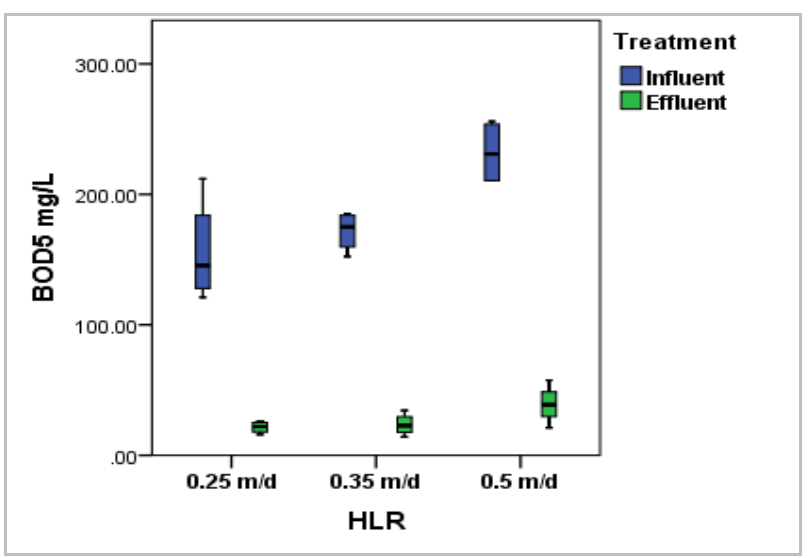

Figure 4. Trend of $\mathrm{BOD}_{5}$ according to HLRs

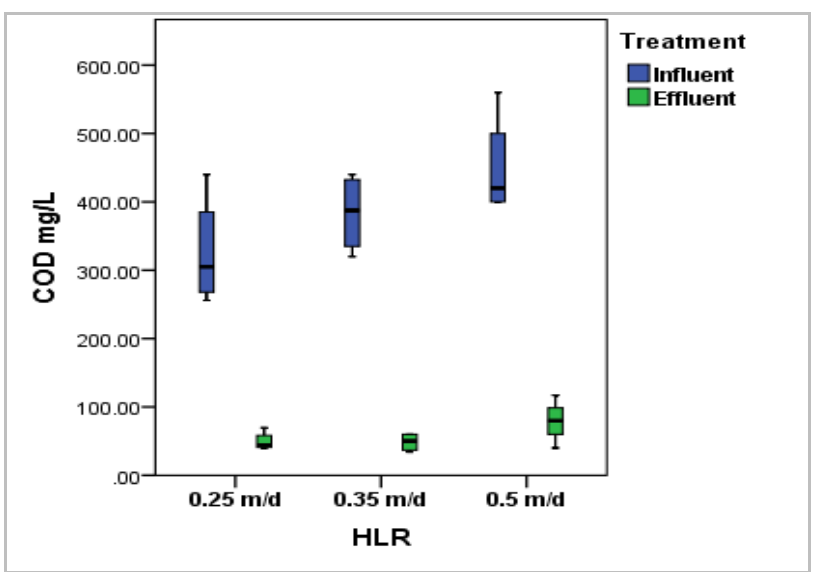

Figure 5. Trend of COD according to HLRs 


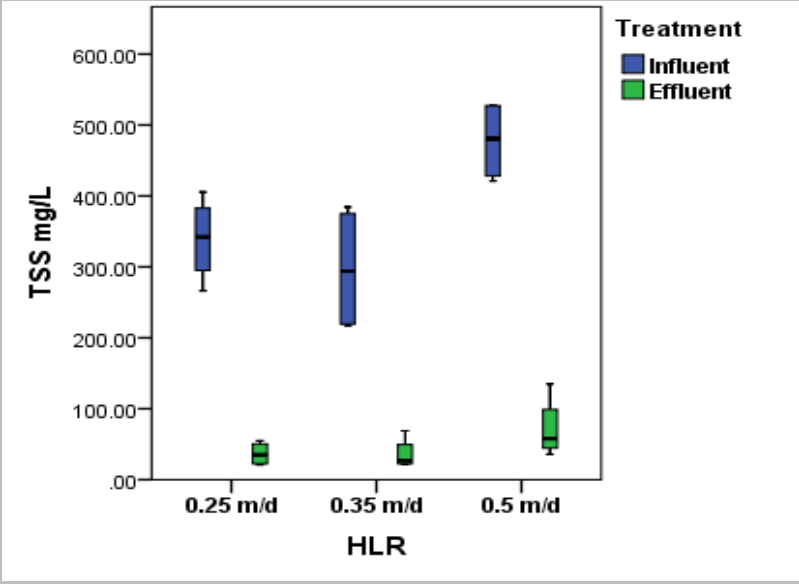

Figure 6. Trend of COD according to HLRs

Moreover, it was suggested that effective contact between the wastewater and SMB was a major factor for MSL performance (Masunaga, et al., 2003; Sato et al., 2005).

The ANOVA test shows that there is a significant difference between the BOD, COD and TSS averages in influent and effluent at $\mathrm{p}<0.05$ (Table 3). However, this test ANOVA did not show any significant difference between the removal rates of these parameters in V-MSL for all HLRs tested at $p<0.05$ (Table 4).

\begin{tabular}{|l|c|c|c|c|}
\hline $\begin{array}{l}\text { Variable } \\
(\mathrm{mg} / \mathrm{L})\end{array}$ & \multicolumn{1}{|c|}{$(\mathrm{I})$} & \multicolumn{1}{c|}{$(\mathrm{J})$} & $\begin{array}{c}\text { Difference } \\
(\mathrm{I}-\mathrm{J})\end{array}$ & $\begin{array}{c}\text { Signification } \\
(\mathrm{p})\end{array}$ \\
\hline BOD5 & Influent & V-MSL & $158.583 * * *$ & .000 \\
$\mathrm{COD}$ & Influent & V-MSL & $327.617 * * *$ & .000 \\
$\mathrm{TSS}$ & Influent & V-MSL & $323.229 * * *$ & .000 \\
$\mathrm{PO}_{4}{ }^{3-}$ & Influent & V-MSL & $3.149 * * *$ & .000 \\
$\mathrm{NH}_{4}{ }^{+}$ & Influent & V-MSL & $9.882 * * *$ & .002 \\
\hline$* * *$ Signfif
\end{tabular}

$* * *$ Significant difference at $\mathrm{p}<0.001$

I: concentration of a specified variable in Influent $\mathbf{J}$ : concentration of a specified variable in Effluent

Table 3. ANOVA test of organic matter between influent and effluent at $p<0.05$

\begin{tabular}{|c|c|c|c|c|}
\hline Variable & (I) HLR & (J) HLR & $\begin{array}{l}\text { Difference } \\
(\mathrm{I}-\mathrm{J})\end{array}$ & $\begin{array}{c}\text { Signification } \\
(\mathrm{P})\end{array}$ \\
\hline \multirow{3}{*}{$\mathrm{BOD}_{5}$} & \multirow{2}{*}{$0.25 \mathrm{~m} / \mathrm{d}$} & $0.35 \mathrm{~m} / \mathrm{d}$ & -.5000 & .994 \\
\hline & & $0.5 \mathrm{~m} / \mathrm{d}$ & 2.0000 & .905 \\
\hline & $0.35 \mathrm{~m} / \mathrm{d}$ & $0.5 \mathrm{~m} / \mathrm{d}$ & 2.5000 & .857 \\
\hline \multirow{3}{*}{ COD } & \multirow{2}{*}{$0.25 \mathrm{~m} / \mathrm{d}$} & $0.35 \mathrm{~m} / \mathrm{d}$ & -3.2500 & .785 \\
\hline & & $0.5 \mathrm{~m} / \mathrm{d}$ & 1.5000 & .949 \\
\hline & $0.35 \mathrm{~m} / \mathrm{d}$ & $0.5 \mathrm{~m} / \mathrm{d}$ & 4.7500 & .606 \\
\hline \multirow{3}{*}{ TSS } & \multirow{2}{*}{$0.25 \mathrm{~m} / \mathrm{d}$} & $0.35 \mathrm{~m} / \mathrm{d}$ & .5000 & .996 \\
\hline & & $0.5 \mathrm{~m} / \mathrm{d}$ & 3.7500 & .790 \\
\hline & $0.35 \mathrm{~m} / \mathrm{d}$ & $0.5 \mathrm{~m} / \mathrm{d}$ & 3.2500 & .837 \\
\hline \multirow{3}{*}{$\mathrm{NH}_{4}^{+}$} & \multirow{3}{*}{$\begin{array}{l}0.25 \mathrm{~m} / \mathrm{d} \\
0.35 \mathrm{~m} / \mathrm{d}\end{array}$} & $0.35 \mathrm{~m} / \mathrm{d}$ & 2.7500 & .850 \\
\hline & & $0.5 \mathrm{~m} / \mathrm{d}$ & 6.7500 & .407 \\
\hline & & $0.5 \mathrm{~m} / \mathrm{d}$ & 4.0000 & .714 \\
\hline \multirow[t]{2}{*}{$\mathrm{PO}_{4}{ }^{3-}$} & \multirow{2}{*}{$0.25 \mathrm{~m} / \mathrm{d}$} & $0.35 \mathrm{~m} / \mathrm{d}$ & 13.5000 & .167 \\
\hline & & $0.5 \mathrm{~m} / \mathrm{d}$ & $26.2500^{*}$ & .009 \\
\hline
\end{tabular}

* Significant difference at $\mathrm{p}<0.05 \quad \mathbf{I}$ and $\mathbf{J}$ : Removal rates of a specified variable at different HLRs $\left(0.25 \mathrm{~m} / \mathrm{d}=250 \mathrm{~L} / \mathrm{m}^{2} /\right.$ day, 0.35 $\mathrm{m} / \mathrm{d}=350 \mathrm{~L} / \mathrm{m}^{2} /$ day and $0.5 \mathrm{~m} / \mathrm{d}=500 \mathrm{~L} / \mathrm{m}^{2} /$ day)

Table 4. ANOVA test of organic and nutrient pollutions removal rates according to HLRs
The differences between removal rates of organic matter (BOD5, COD and TSS) in our filter did not exceed 5\%. This result can be explain by the V-MSL ability to treat domestic wastewater with hydraulic loading rates less than or equal to $500 \mathrm{~L} / \mathrm{m}^{2} /$ day. Indeed, the high removal rates of organic pollutants (BOD5, COD and TSS) reported in this study, indicate the importance of physical (filtration, sedimentation), chemical (adsorption, precipitation) and biological (biodegradation) mechanisms occurring in our MSL system.

Similar results were reported by Lamzouri et al., (2016) that investigated the performance of three full-scale V-MSL (MSL1: HLR-250L/ $\mathrm{m}^{2} /$ day, MSL2: HLR-500L $/ \mathrm{m}^{2} /$ day and MSL3: HLR-1000L $/ \mathrm{m}^{2} /$ day). They reported for COD, $\mathrm{BOD}_{5}$, TSS the following results $(86 \%, 82 \%$ and $89 \%)$ for MSL1, respectively; $(83 \%, 77 \%$ and $86 \%)$ for MSL2, respectively and $(78 \%, 71 \%$ and $83 \%$ ) for MSL3, respectively. In addition, Sato et al., (2011a) reported that in a pilot-scale study the removal rates were $91 \%$ for $\mathrm{BOD}_{5}$ and $85 \%$ for COD. Also, Masunaga et al., (2007) reported removal rates between $88 \%$ and $98 \%$ for BOD5. The reduction of organic matter is realized through biological degradation under oxygenated condition in the porosity of the MSL reactor (Chen et al., 2009).

On the other hand, the efficiency (per cent removal by mass) of the V-MSL to remove organic matters according to the seasons is showed in Table 5 and Figure 7. This filter showed a high performance to remove the $\mathrm{BOD}_{5}, \mathrm{COD}$ and TSS during all season with an average between $81.5 \%$ - $85 \%$ in summer, $84 \%$ $87 \%$ in fall, $83 \%-89 \%$ in winter and $84 \%-88 \%$ in spring. These results show that the V-MSL filter shows certain stability to remove organic matter, this is might be related to the optimum temperatures (between $12^{\circ} \mathrm{C}$ and $29^{\circ} \mathrm{C}$ ) and dissolved oxygen (with an average of $4 \mathrm{mg} / \mathrm{L}$ ) recorded during the study period (Table 1). According to Zhu and Chen (2002), biological reaction rates increase with rising temperature until an optimal temperature is reached; above the optimal temperature, enzymatic proteins denature and the rates decrease in fixed film processes. On the other hand, Latrach et al., (2018) reported that the efficiency of MSL technology to reduce contaminants is not sensitive to season and air temperature fluctuations.

\begin{tabular}{|l|l|l|l|l|l|}
\hline \multirow{2}{*}{} & \multicolumn{5}{|c|}{ Removal rates (\%) } \\
\cline { 2 - 6 } & BOD 5 & COD & TSS & $\mathrm{PO}_{4}{ }^{3-}$ & $\mathrm{NH}_{4}{ }^{+}$ \\
\hline Summer & 81.5 & 82.9 & 85.7 & 71.85 & 84.4 \\
Fall & 87.3 & 87.1 & 84.1 & 65.4 & 84.7 \\
Winter & 83.3 & 82.9 & 89.7 & 76.9 & 83.7 \\
Spring & 86.8 & 84.4 & 88.3 & 75.5 & 79.6 \\
\hline
\end{tabular}

Table 5. Efficiency of V-MSL to remove the pollutions according to the season

This is due to the capacity of MSL system materials to withstand the air temperature variation, which highlights one of the advantages of MSL's technology. Contrarily, according to Taylor et al., (2011) and Stefanakis \& Tsihrintzis, (2012), the effect of season and temperature on organic matter removal efficiency in the constructed wetlands is reported with the worst performance occurring usually during the winter with low temperatures. 

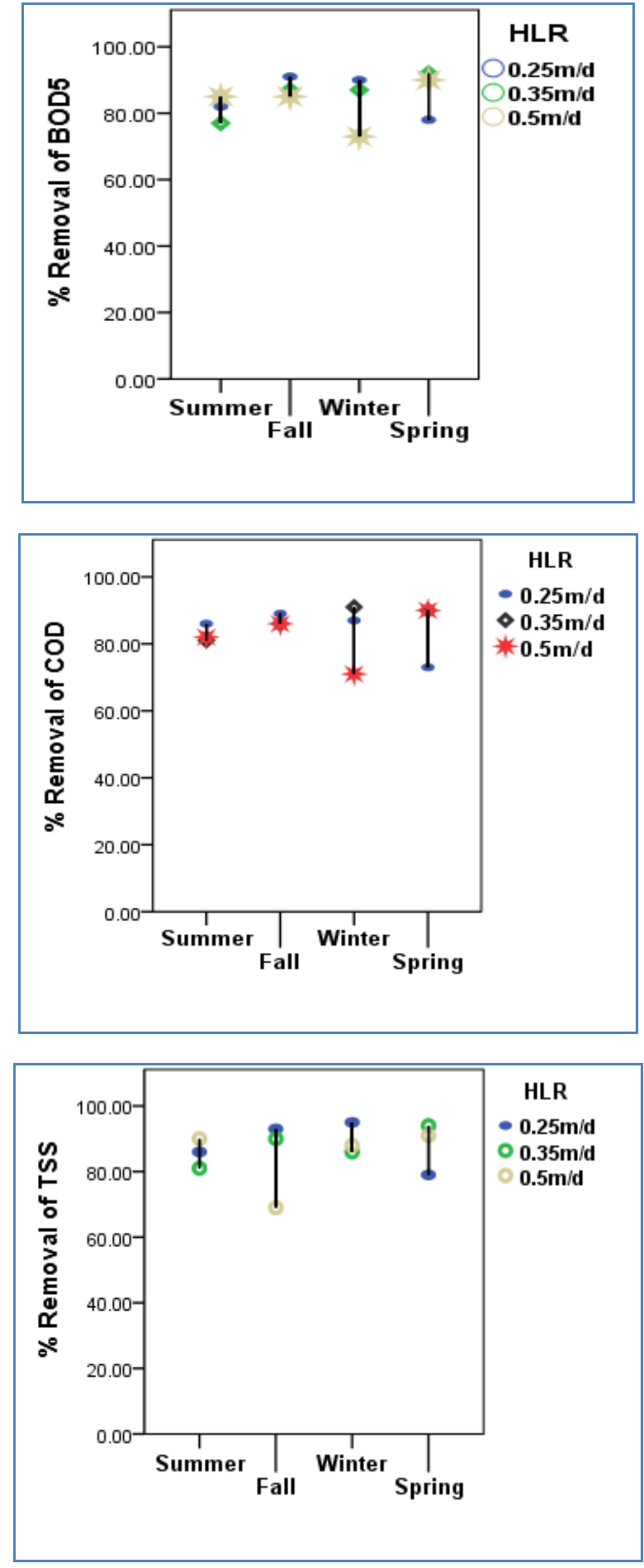

Figure 7. Performance of V-MSL to remove organic matters according to HLR and season

\subsection{Ammonia removal and nitrate transformation}

Table 6 and Figure 8 show the average concentrations of ammonia in influent and effluent during the study period according to the HLRs. With HLR $1=250 \mathrm{~L} / \mathrm{m}^{2} /$ day, NH4+ concentrations were $(15.4 \pm 4.4) \mathrm{mg} / \mathrm{L}$ and $(2.1 \pm 1.6) \mathrm{mg} / \mathrm{L}$, respectively. Under HLR2 $=350 \mathrm{~L} / \mathrm{m}^{2} /$ day, $\mathrm{NH}^{+}$concentrations were $(20.1 \pm 1.8) \mathrm{mg} / \mathrm{L}$ and $(3.4 \pm 1.4) \mathrm{mg} / \mathrm{L}$, respectively. Finally, with $\mathrm{HLR} 3=500 \mathrm{~L} / \mathrm{m}^{2} /$ day, $\mathrm{NH}^{+}$concentrations were (24.0 \pm 5.7$) \mathrm{mg} / \mathrm{L}$ and $(4.9 \pm 1.3) \mathrm{mg} / \mathrm{L}$, respectively. This indicates that the nitrification was effective due to aerobic conditions into the filter. The average removal rates of NH4+ were $(86.3 \pm 10.7) \%,(83.5 \pm 5.7) \%$ and $(79.5 . \pm 1.7) \%$ for the three HLRs tested (HLR1, HLR2 and HLR3), respectively. Despite these differences between the three HRLs tested, ANOVA test did not show any difference of the NH4+ removal between the three HLRs at $p<0.05$ (Table 4). However, this test showed a significant difference between $\mathrm{NH} 4+$ averages in influent and effluent at $\mathrm{p}<0.001$ (Table 3).

\begin{tabular}{|l|l|l|l|}
\hline HLR $\left(\mathrm{L} / \mathrm{m}^{2} /\right.$ day $)$ & & $\mathrm{NH}_{4}{ }^{+}$ & $\mathrm{PO}_{4}{ }^{3-}$ \\
\hline \multirow{3}{*}{250} & Influent(mg/L) & $15.4 \pm 4$ & $5.0 \pm 2.7$ \\
& V-MSL (mg/L) & $2.1 \pm 1.6$ & $0.70 \pm 0.3$ \\
& $\%$ removal & $86.3 \pm 10$ & $85.7 \pm 3.8$ \\
& Influent (mg/L) & $20.1 \pm 1$ & $4.0 \pm 0.7$ \\
& V-MSL (mg/L) & $3.4 \pm 1.4$ & $1.1 \pm 0.5$ \\
& \% removal & $83.5 \pm 5$ & $72.3 \pm 11.6$ \\
& Influent (mg/L) & $24.0 \pm 5$ & $3.9 \pm 0.7$ \\
& V-MSL (mg/L) & $4.9 \pm 1.3$ & $1.6 \pm 0.7$ \\
& \% removal & $79.5 . \pm 1$ & $59.5 \pm 11.2$ \\
\hline
\end{tabular}

Table 6. Removal performance of nutrients under different HLRs

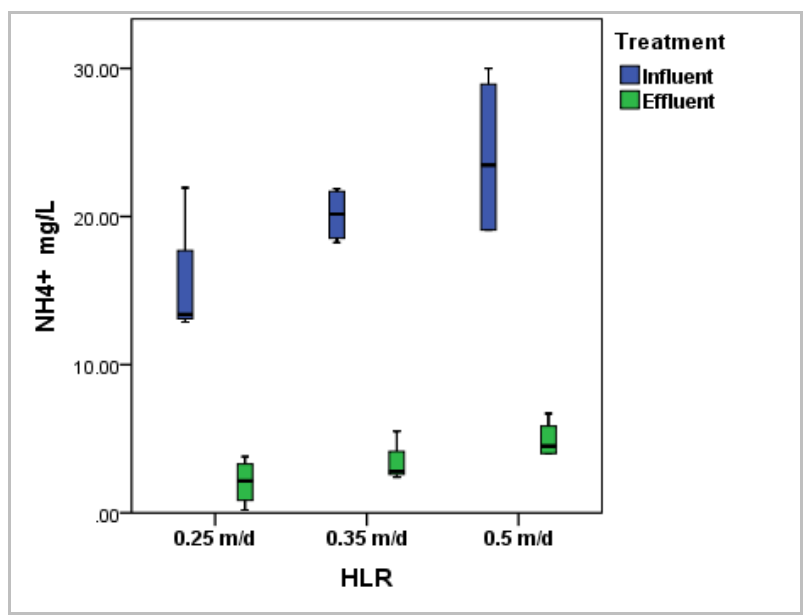

Figure 8. Trend of Ammonia according to HLR

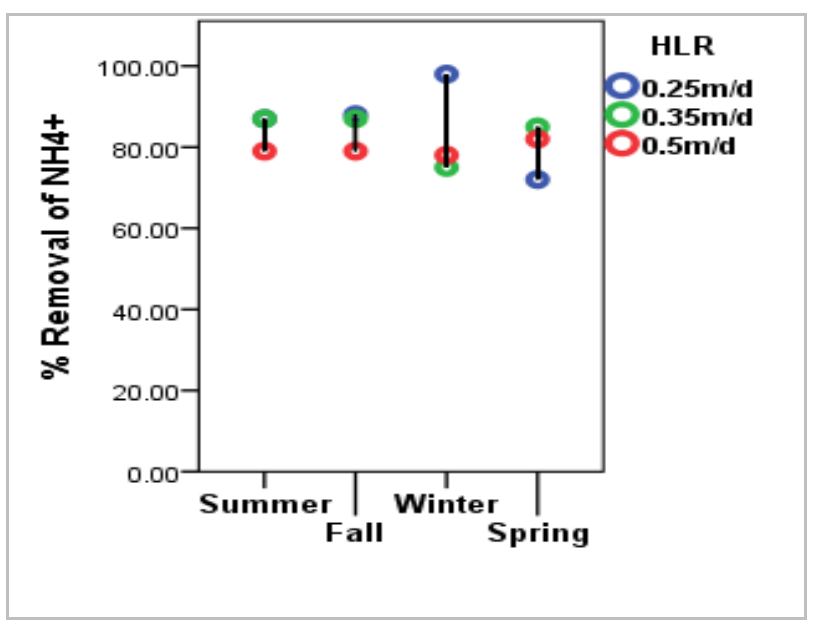

Figure 9. Performance of V-MSL 
The high removal efficiency for nitrogen was due to the ability of the MSL materials to adsorb $\mathrm{NH}_{4}{ }^{+}$and to the co-existence of aerobic and anaerobic conditions inside the MSL system that induce nitrification/denitrification processes. Sato et al., (2011b) showed that nitrification took place in permeable layers and SMBs in the top layers of MSL system. However, denitrification mainly occurred in the lower SMBs. Nitrates were produced in the upper part of the MSL system and its concentrations decreased in the lower part where anaerobic conditions were developed indicating that denitrification proceeded (Sato et al., 2011b).

In Moroccan conditions, Lamzouri et al., (2016) reported similar result for MSL1 (HLR-250L/m²/day) which reached $85 \%$ of $\mathrm{NH}_{4}{ }^{+}$removal. However, our results are better for $\mathrm{HLR}=500 \mathrm{~L} / \mathrm{m}^{2} /$ day since they reported only $71 \%$ of ammonium removal. Also, Latrach et al., (2016) reported the same result for MSL pilot in term of $\mathrm{NH}_{4}{ }^{+}$removal. On the other hand, the efficiency the V-MSL showed a good performance to remove ammonium according to the season (Table 5 and Figure 9). The average removal rates are $84.4 \pm 4.7 \%, 84.7 \pm 5 \%, 83.7 \pm 12.9 \%$ and $79.6 \pm 7 \%$ in summer, fall, winter and spring, respectively. This filter shows a certain stability to remove $\mathrm{NH}_{4}{ }^{+}$during the study period (Latrach et al., 2018).

\subsection{Elimination of orthophosphate}

The $\mathrm{P}_{4}{ }^{3-}$ average concentrations in influent and effluent during the study period according to the HLRs were $(5.0 \pm 2.7) \mathrm{mg} / \mathrm{L}$ and $(0.70 \pm 0.35) \mathrm{mg} / \mathrm{L}$, respectively (with $\mathrm{HLR} 1=250 \mathrm{~L} / \mathrm{m}^{2} /$ day); under $\mathrm{HLR} 2=350 \mathrm{~L} / \mathrm{m}^{2} /$ day, the $\mathrm{P}_{4}{ }^{3-}$ concentrations were $(4.0 \pm 0.7) \mathrm{mg} / \mathrm{L}$ and $(1.1 \pm 0.5) \mathrm{mg} / \mathrm{L}$, respectively; finally, with $\mathrm{HLR} 3=500 \mathrm{~L} / \mathrm{m}^{2} /$ day, the $\mathrm{P}_{4}{ }^{3-}$ concentrations were $(3.9 \pm 0.7)$ $\mathrm{mg} / \mathrm{L}$ and $(1.6 \pm 0.7) \mathrm{mg} / \mathrm{L}$, respectively (Table 7 and Figure 10). The average removal rate of $\mathrm{P}_{4}{ }^{3-}$ during the study period was $72.5 \%$, while their removal rates for the three HLRs tested $(250$ $\mathrm{L} / \mathrm{m}^{2} /$ day, $350 \mathrm{~L} / \mathrm{m}^{2} /$ day and $500 \mathrm{~L} / \mathrm{m}^{2} /$ day) were $(85.7 \pm 3.8) \%$, $(72.3 \pm 11.6) \%$, and $(59.5 \pm 11.2) \%$, respectively (Table 7 and Figure 11). The ANOVA test showed that there is a significant difference between the P043- means of the V-MSL and the influent at $\mathrm{p}<0.001$ (Table 3), and between the hydraulic loading rates $250 \mathrm{~L} / \mathrm{m}^{2} /$ day and $500 \mathrm{~L} / \mathrm{m} 2 /$ day; but it did not show any significant difference between $250 \mathrm{~L} / \mathrm{m}^{2} /$ day, 350 $\mathrm{L} / \mathrm{m}^{2} /$ day (Table 4 ).

Lamzouri et al., (2016) reported a high removal rates of $\mathrm{P}_{4} 4^{3-}$ $91 \%, 86 \%$ and $81 \%$ for the three HLRs $\left(250 \mathrm{~L} / \mathrm{m}^{2} /\right.$ day, $500 \mathrm{~L} / \mathrm{m}^{2} /$ day and $1000 \mathrm{~L} / \mathrm{m}^{2} /$ day), respectively, in Moroccan conditions. According to several studies, the MSL system was very effective in removing phosphorus, because of the capacity of the soil and iron existing into the SMB blocks to adsorb and/or precipitate phosphate from the wastewater (Drizo et al., 2006). Furthermore, it has been reported that phosphorus removal increases with increasing retention time, due to increased contact time (Lantzke et al., 1999; Taouraout, et al., 2019). This indicates that retention time is a crucial parameter for effective phosphorus removal (Drizo et al., 2006). In addition, according to Luanmanee et al., (2003), aeration of the system is also an important factor in improving phosphorus removal from wastewater. Indeed, aeration enhanced phosphorus removal by forming ferric hydroxides, which strongly fixed phosphate from the wastewater. After aeration was stopped, anaerobic conditions developed in the MSL system. This enhanced the formation of ferrous ions, which are not effective in fixing phosphate (Masunaga, Wakatsuki, 1999; Wakatsuki et al., 2000). Indeed, the iron added to the SMBs is transformed into ferrous iron $\left(\mathrm{Fe}^{2+}\right)$, which is transported to the gravel layers and is oxidized under aerobic conditions to ferric ion $\left(\mathrm{Fe}^{3+}\right)$; then, $\mathrm{P}_{4}{ }^{3-}$ from wastewater precipitate with $\mathrm{Fe}^{3+}$ (Wakatsuki et al., 1993; Chen et al., 2009; An et al., 2016). The V-MSL showed a good performance to remove $\mathrm{PO}_{4}{ }^{3-}$ according to the season (Table 5 and Figure 11). The average removal rates are $71.85 \pm 11.6 \%, 65.4 \pm 14.8 \%, \quad 76.9 \pm 10.8 \%$ and $75.5 \pm 22.3 \%$ in summer, fall, winter and spring, respectively.

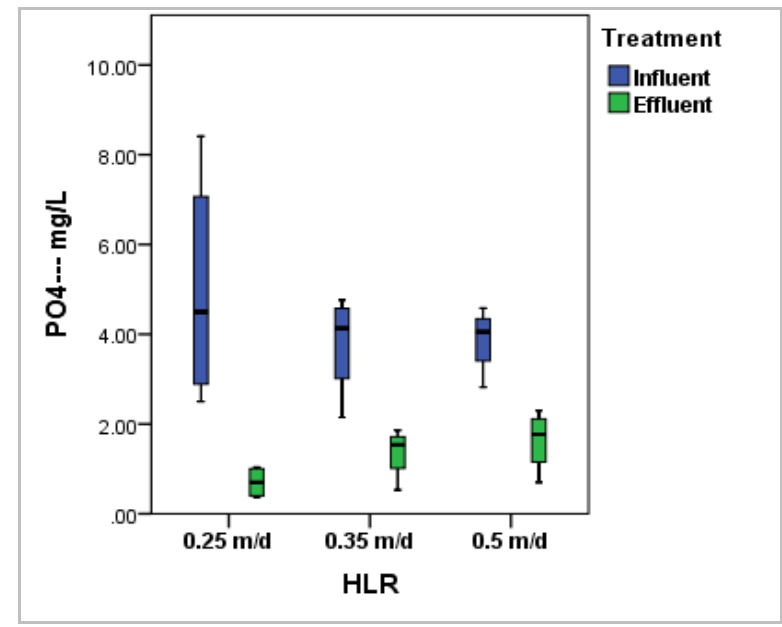

Figure 10. Trend of $\mathrm{P}_{4}{ }^{3-}$ removal

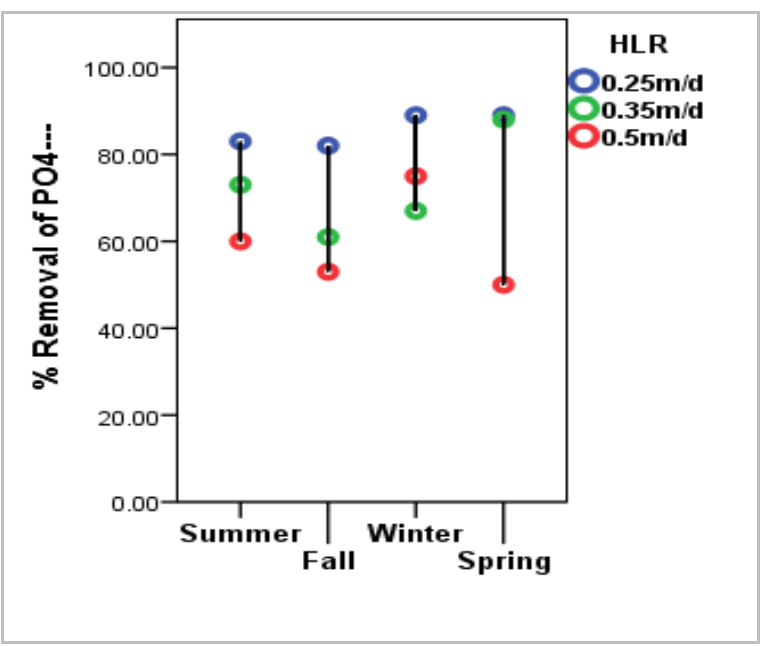

Figure 11. Removal rate of $\mathrm{P}_{4}{ }^{3-}$ according to season

\section{CONCLUSION}

The Vertical Multi-Soil-Layering system used in this study showed a good ability to reduce $\mathrm{BOD}_{5}, \mathrm{COD}, \mathrm{TSS}, \mathrm{NH}_{4}^{+}$since the removal efficiencies of these parameters are over than $80 \%$ for all the three hydraulic load rates used. This system showed also a good performance to reduce $\mathrm{P}_{4^{3-}}$ with $\mathrm{HLR}=250$ $\mathrm{L} / \mathrm{m}^{2} /$ day, but for the other HLRs tested, it recorded a moderate performance (between 60\% and 72\%). Furthermore, the efficiency of the V-MSL to reduce contaminants is not sensitive to season. In all, the effluent quality (physico-chemical) in this study was still in line with Moroccan standards. However, a study of the effectiveness of this system in eliminating faecal pollution and parasites would be necessary under Moroccan conditions. 
In general, this system is assumed to be one of the alternative technologies for decentralized wastewater treatment in smart city.

\section{ACKNOWLEDGEMENTS}

Our thanks to the manager of a middle School (Razi, Meknes) and the guardian for their assistance.

\section{REFERENCES}

An, C. J., Mcbean, E., Huang, G. H., Yao, Y., Zhang, P., Chen, X. J., Li, Y. P., 2016: Multi-Soil-Layering Systems for Wastewater Treatment in Small and Remote Communities; 27:131-144. https://doi.org/10.3808/jei.201500328

Berrada, 2007 : Assainissement non collectif dans la province de Kénitra, analyses et perspectives.

Chen, X., Luo, A.C., Sato, K., Wakasuki, T., Masunaga, T., 2009: An introduction of a multi-soil-layering system: A novel green technology for wastewater treatment in rural areas. Water Environ. J.,23, 255-262.

Drizo, A., Forget, C., Chapuis, R. P., Comeau, Y., 2006: Phosphorus removal by electric arc furnace steel slag and serpentinite. Water Research; 40: 1547.

Farmer, AM., 2001: Reducing phosphate discharges: the role of the 1991 EC Urban Wastewater Treatment Directive. Water SciTechnol,; 44:41-48.

Ferguson, G., Dakers, A., and Gunn, I., 2003: Sustainable wasrewater management. A handbook for smaller communities. Published by the ministry for the environment Manatu Mo Te Taiao, New Zealand. ISBN: 0-478-24094-5

Galloway, J.N., Dentener, F.J., Capone, D.G., Boyer, E.W., Howarth, R.W., Seitzinger, S.P., Asner, G.P., Cleveland, C.C., Green, P.A., Holland, E.A. 2004: Nitrogen cycles: past, present, and future. Biogeochemistry; 70:153-226.

Guan, Y., Zhang, Y., Huang, X., Fu, J., 2015: Effect of operating factors on the contaminants removal of a soil filter: multi-soil-layering system. Environmental Earth Sciences; 74:2679-2686.

Heinonen-Tanski, H., van Wijk-Sijbesma, C., 2005: Human excreta for plant production. BioresourTechnol; 96:403-411.

Ho, C., and Wang, P., 2015: Efficiency of a Multi-SoilLayering System on Wastewater Treatment Using EnvironmentFriendly Filter Materials, (3), 3362-3380. https://doi.org/10.3390/ijerph120303362.

Jewitt, S.. 2011: Poo gurus? Researching the threats and opportunities presented by human waste. ApplGeogr; 31:761769. This paper provides a good overview of the importance of human waste (as both a threat and an opportunity) in different spatial, historical and cultural contexts and highlights potential areas of interest for applied geographical research in the future.

Lamzouri, K., Mahi, M., Ouatar, S., Bartali, E., Masunaga, T., Latrach, L., Mandi, L., 2016: Application of Multi-soil-layering technique for wastewater treatment in Moroccan rural areas: study of the operation process for an engineering design. Journal of Materials and Environmental Science; 7:579-585.
Lantzke, I. R., Mitschell, D. S., Heritage, A. D., Sharma, K. P., 1999: A model of factors controlling orthophosphate removal in planted vertical flow wetlands. Ecological Engineering; 12: 93 105.

Latrach, L., Ouazzani, N., Hejjaja, A., Mahi, M., Masunaga, T., Mandi, L., 2018b: Two-stage vertical flow multi-soil-layering (MSL) technology for efficient removal of coliforms and human pathogens from domestic wastewater in rural areas under arid climate. International Journal of Hygiene and Environmental Health 221 (2018) 64-80, http://dx,doi,org/10,1016/j,ijheh,2017,10,004

Latrach, L., Ouazzani, N., Masunaga, T., Hejjaj, A., Bouhoum, K., Mahi, M., Mandi, L., 2016: Domestic wastewater disinfection by combined treatment using multi-soil-layering system and sand filters (MSL-SF): A laboratory pilot study. Ecological Engineering, https://doi.org/10.1016/j.ecoleng.2016.02.036

Luanmanee, S., Attanandana, T., Masunaga, T., Wakatsuki, T., Chemistry, S., Division, S. S., Science, E., 2003: Treatment of domestic wastewater with a multi-soil-layering ( MSL ) system in a temperate and a tropical climate, 1-8.

Luanmanee, S., Boonsook, P., Attanandana, T., Saitthiti, B., Panichajakul, C., Wakatsuki, T., 2002: Effect of intermittent aeration regulation of a multi-soil-layering system on domestic wastewater treatment in Thailand. Ecol. Eng., 18, 415-428.

Masunaga, T., Wakatsuki, T., 1999: High quality water remediation by the Multi Soil Layering Method. In: Chemistry for Protection of the Environment. Proceedings of the 12th International Conference on Chemistry for Protection of the Environment, Nanjing University Press, Nanjing, China; 303309.

Masunaga, T., Sato, K., Shirahama, M., Kudo, H., Wakatsuki, T., 2007: Characteristics of wastewater treatment using a multisoil-layering system in relation to wastewater contamination levels and hydraulic loading rates. Soil Sci. Plant Nutr., 53, 215-223.

Masunaga, T., Sato, K., Zennami, T., Fujii. S., Wakatsuki, T., 2003: Direct treatment of polluted river water by the multi-soillayering method. Journal of Water and Environment Technology; 1:97-104. http:// dx.doi.org/10.2965/jwet.2003.97

Rodier J., Legube B., Merlet N. et coll., 2009: Analyse de l'eau (eaux naturelles, eaux résiduaires, eau de mer) : physicochimie, microbiologie, biologie, interprétation des résultats, 9ème édition, Dunod, Paris, 1 .

Sato, K., Iwashima, N., Wakatsuki, T., and Masunaga, T., 2011a: Clarification of water movement properties in a multisoil-layering system. Soil Sci. Plant Nutr., 57(4), 607-618. http://dx.doi.org/10.1080/00380768.2011.594966

Sato, K., Iwashima, N., Wakatsuki, T., Masunaga, T., 2011b: Quantitative evaluation of treatment processes and mechanisms of organic matter phosphorus, and nitrogen removal in a multisoil-layering system. Soil Science and Plant Nutrition; 57:475486.

Sato, K., Masunaga, T., and Wakatsuki, T., 2005: Water movement characteristics in a multi-soil-layering system. Soil 
Sci. Plant Nutr., 51(1),75-82.http://dx.doi.org/10.1111/j.174707 65.2005.tb00009.x

Stefanakis, AI., Tsihrintzis, VA., 2012: Effects of loading, resting period, temperature, porousmedia, vegetation and aeration on performance of pilot-scale vertical flow constructed wetlands. Chemical Engineering Journal; 181-182, 416-430.

Sutton MA, Howard CM, Willem Erisman J, Billen G, Bleeker A, Grennfelt P, vanGrinsven H, Grizzetti B (Eds) 2011: European Nitrogen Assessment: Sources, Effects and Policy Perspectives. University of Cambridge Press.

Taouraout, A., Chahlaoui, A., Belghyti, D., Sammoudi, R., Najy, M., 2020a: How to Improve Wastewater Treatment in Smart City. (C) Springer Nature Switzerland AG 2020 M. Ben Ahmed et al. (Eds.): SCA 2019, LNITI, pp. 1141-1153. https://doi.org/10.1007/978-3-030-37629-1_82

Taouraout, A., Chahlaoui, A., Belghyti, D., Taha, I., Ouarrak, K., Sammoudi, R., 2019: Hydraulic load rates effect on the performance of Horizontal Multi-Soil-Layering to treat domestic wastewater in rural areas of Morocco. Journal of Materials and Environmental Science, 2019, Volume 10, Issue5, Page 422-430

Taouraout, A., Chahlaoui, A., Belghyti,, D., Taha, I., Ouarrak. K., 2020b : Improving Safe and Sustainable Gray Water Reuse: A New Solution to Curb Water Shortages in Moroccan Cities. (C) Springer Nature Switzerland AG 2020 M. Ben Ahmed et al. (Eds.): SCA 2019, LNITI, pp. 1167-1178. https://doi.org/10.1007/978-3-030-37629-1_84

Taylor, CR., Hook, P. B., Steinc, OR., Zabinski, CA., 2011: Seasonal effects of 19 plant species on COD removal in subsurface treatment wetland microcosms. Ecological Engineering; 37, 703-710.

UN-HABITAT, 2009: State of the World's Cities - Harmonious Cities! 2008/9.UN-HABITAT.

UNICEF/WHO, 2008: World Health Organization and United Nations Children's Fund Joint Monitoring Programme for Water Supply and Sanitation (JMP): Progress on Drinking Water and Sanitation: Special Focus on Sanitation.

United Nations, 2016: Agenda items 5, 6 and 18 (a) High level segment High-level political forum on sustainable development, convened under the auspices of the Economic and Social Council Economic and environmental questions: sustainable development Progress towards the Sustainable Development Goals Report of the Secretary-General.

Vymazal, J.,. 2011: Plants used in constructed wetlands with horizontal subsurface flow: a review. Hydrobiologia 674, 133156.

Wakatsuki, T., Esumi, H., Omura, S., 1993: High performance and $\mathrm{N}$ and $\mathrm{P}$ removable on- site domestic wastewater treatment system by Multi-Soil-Layering method. Water Science and Technology ; 27, 31-40.

Wakatsuki, T., Luanmanee, S., Masunaga, T., Attanandana, T., 2000: High grade on-site treatment of domestic wastewater and polluted river water by Multi-Soil-Layering method. In: Managing Water and Waste in the New Millennium. Proceedings of the IWA (International Water Association) Conference, May, Johannesburg, South Africa.
WHO, 2005: Guidelines for the safe use of wastewater and excreta in agriculture and aquaculture. Draft.

Wu, S., Kuschk, P., Brix, H., Vymazal, J., Dong, R., 2014: Development of constructed wetlands in performance intensifications for wastewater treatment: a nitrogen and organic matter targeted review. Water Res. 57C, 40-55.

Zhu, S., Chen, S., 2002: The impact of temperature on nitrification rate in fixed film biofilters. Aquacultural Engineering; 26:221-237. 